УДК 343.98

DOI https://doi.org/10.32849/2663-5313/2020.4.51

\title{
Віктор Костенецький,
}

здобувач магістра права

Вінницького інституту

Міжрегіональної академії управління персоналом

\section{МІЖНАРОДНИЙ ДОСВІД КРИМІНАЛЬНО-ПРАВОВОЇ ПРОТИДІЇ ТЕРОРИЗМУ}

У статті проводиться огляд антитерористичного законодавства країн Західної Європи, виявляються спільні єдині тендениї ставлення до такого негативного кримінального явища, яким загальновизнано тероризм. Цей вид злочину розглянуто з точки зору кримінально-правового регулювання питань відповідальності за тероризм у зарубіжних державах, в якому проглядається вплив історичних традииій відповідної держави. За результатами аналізу законодавства зарубіжних держав нами не виявлено положень, які дочільно негайно й безальтернативно імплементувати у чинне начіональне законодавство. Визначено, шо темпи вироблення власних дефінічій терміна «тероризм» та їх закріплення в начіональному законодавстві багато в чому залежать від того, як давно окремі держави зіткнулися з иією проблемою і як далеко зайшло протистояння між власними владними структурами та суспільством, з одного боку, і терористичними організаціями - з іншого. Наголошено, що у більшості країн стаття про кримінальну відповідальність за тероризм чи терористичний акт складається з кількох частин. У них, як правило, диферениіюється відповідальність за тероризм (терористичний акт), хоча в окремих з них можуть формулюватися положення про відповідальність за, по суті, самостійні злочинні діяння. Зроблено такі висновки: 1) антитерористичне законодавство країн Західної Європи характеризується загальними тендениіями до такого негативного злочинного явища, яке широко визнається; 2) тероризм у кримінально-правовому регулюванні питань відповідальності за тероризм у зарубіжних країнах вивчає вплив історичних традичій відповідної держави; 3) за результатами аналізу законодавства зарубіжних держав ми не визначили жодних положень, які дочільно негайно та безальтернативно впровадити в чинне начіональне законодавство. Забігаючи наперед, слід визнати, шо чинне начіональне кримінальне законодавство, що стосується відповідальності за тероризм, загалом відповідає європейським тендениіям. Інше питання: чи повністю воно відповідає вимогам сьогодення? Відповідь на че питання потребує ретельного та всебічного аналітичного підходу до розробки приниипів контртероризму з урахуванням визначення ивого виду злочину.

Ключові слова: антитерористичне законодавство, терористична група, терористична організація, позбавлення волі.

Постановка проблеми. Міжнародна спільнота вже давно прагне скоординувати зусилля держав, різних громадських організацій, благодійних фондів на протидію тероризму, при цьому особливе значення надається правовій сфері у вирішенні цієї глобальної проблеми, насамперед іï кримінальноправовому складнику. Це знаходить свій вияв, зокрема, у тенденції до розширення заходів, спрямованих на криміналізацію переслідувань за терористичні діяння у численних міжнародно-правових документах, чимало визначальних положень яких імплементується і в національних законодавствах. Так, згідно 3 п. 9 резолюції 3034, прийнятої Генеральною Асамблеєю ООН у грудні 1973 р., утворено Спеціальний Комітет 3 міжнародного тероризму. У Преамбулі Декларації ООН «Про заходи ліквідації міжнародного тероризму» від 9 грудня 1994 р. зазначено: «Припинення актів міжнародного тероризму, включаючи ті, в яких прямо або опосередковано беруть участь держави, слугує одним із найважливіших елементів для підтримки міжнародного миру і безпеки» [39].

Держави-члени ЄС 27 січня 1977 р. прийняли Європейську конвенцію про боротьбу 3 тероризмом. На Генеральній Асамблеї ООН 15 грудня 1997 р. ухвалено Міжнародну конвенцію про боротьбу з бомбовим тероризмом, а 9 грудня 1999 р. Міжнародну конвенцію про боротьбу з фінансуванням тероризму, 15 травня 2003 р. був відкритий для підписання Протокол, що вносить зміни до Європейської конвенції про боротьбу 3 тероризмом.

Аналіз досліджень і публікацій. Не оминула увагою цієї комплексної проблеми 
і вітчизняна наука. Так, ще в радянський час окремі її аспекти висвітлювалися у публікаціях Н.С. Бєглової, І.П. Бліщенко, Т.С. БоярСозонович, В.В. Вітюка, Л.М. Галенської, О.В. Епель, С.А. Ефірова, В.П. Ємельянова Н.В. Жданова, Ю.В. Землянського, А.Е. Ізетова, І. І. Карпеця, Н.Б. Крилова, У.Р. Латипова, Є.Г. Ляхова, Л.О. Моджорян, Л.В. Новікова, Ю.О. Решетова, М.В. Семикіна та ін. Однак треба визнати, що в роботах цих учених тероризм розглядався здебільшого як злочинні акти з боку екстремістськи налаштованих елементів і груп, тобто вважався злочином, що кваліфікувався за ознаками бандитизму.

3 огляду на міжнародний характер проблем протидії тероризму їх дослідженню присвячено чимало доробків зарубіжних учених, з-поміж яких слід виокремити праці Р.А. Адельханяна, Ю.М. Антоняна, I.І. Артамонова, В.А. Васильєва, П. Вілкінсона, Б.Я. Гаврилова, Х.П. Гассера, С.У. Дікаєва, А.І. Долгової, М. Креншоу, В. Лакера, Г.М. Міньковського, М.Ф. Мусаеляна, Г.В. Овчіннікової, І.Л. Трунова, В.В. Устінова, О.М. Хлобоустова, Б. Хофмана та ін.

Метою статті є огляд антитерористичного законодавства країн Західної Свропи; виявлення спільних тенденцій ставлення до такого негативного кримінального явища яким загальновизнано тероризм; розгляд тероризму з точки зору кримінально-правового регулювання питань відповідальності за тероризм у зарубіжних державах, в якому проглядається вплив історичних традицій відповідної держави.

Виклад основного матеріалу. За останні 40 років у сфері боротьби 3 міжнародним тероризмом в рамках ООН та їі спеціалізованих структур прийняті 13 основних міжнародних договорів, у рамках Ради Європи - 7 договорів. Незважаючи на значну увагу, яка приділяється міжнародною спільнотою проблемі протидії тероризму, питання визначення міжнародного тероризму залишається відкритим. На думку німецького дослідника Екхарта фон Бубноффа, складність всеохоплюючого визначення міжнародного тероризму пояснюється багатоплановістю його проявів, мотивами та особливостями терористичної діяльності. Універсальне визначення міжнародного тероризму необхідне для вироблення несуперечливого конвенційного механізму протидії йому. Принагідно зазначимо, що Індія подала на розгляд ООН проєкт Всеохоплюючої конвенції по боротьбі з міжнародним тероризмом, в якій має місце прагнення задіяти потенціал міжнародного права у боротьбі з тероризмом.
У Резолюції 1456, прийнятій Радою Безпеки ООН на їі засіданні 20 січня 2003 р., зокрема, сказано, що «тероризм можна перемогти лише шляхом застосування відповідно до Статусу Організації Об'єднаних Націй і міжнародного права стійкого всеохоплюючого підходу, що включає активну участь і співробітництво всіх держав, міжнародних і релігійних організацій, а також шляхом активізації зусиль на національному рівні» [2].

Основи боротьби 3 тероризмом можуть визначатися не лише нормами міжнародного права, а й національними законами. Так, 20 березня 2003 р. в Україні прийнято Закон «Про боротьбу з тероризмом». Такі закони $є$ в багатьох інших державах, зокрема в Російській Федерації, Франції, Іспанії, США.

Темпи вироблення власних дефініцій терміна «тероризм» та їх закріплення в національному законодавстві багато в чому залежать від того, як давно окремі держави зіткнулися 3 цією проблемою і як далеко зайшло протистояння між власними владними структурами та суспільством, з одного боку, і терористичними організаціями з іншого. Прикладом подібного підходу може слугувати досвід США, які намагаються детально регламентувати своє законодавство в розділах, пов'язаних з протидією терористичній діяльності. Однак, як зазначає відомий американський аналітик Б. Хоффман, який займається проблемами тероризму, навіть у рамках окремо взятої країни процес формування єдиної дефініції терміна «тероризм» наштовхується на досить значні труднощі. Основними серед них є розбіжності у підходах до визначення самого поняття «тероризм», зумовлені різноманітними функціями, що покладаються на державні відомства, покликані боротися з терористичними проявами усередині країни та за ії межами. Згаданий аналітик виокремлює деякі дефініції, прийняті Державним департаментом США, Федеральним бюро розслідування (ФБР) і Міністерством оборони США.

В офіційному визначенні тероризму, сформульованому Державним департаментом США, зазначається, що це «завчасно обдумане, політично мотивоване насильство, що застосовується проти мішеней, які не беруть участі у воєнних діях (noncombatant targets), субнаціональними групами або підпільними державними агентами» [3, с. 78-82]. Тут виділяється насамперед політична мотивація терору, що дає змогу одразу ж відокремити, наприклад, мафіозні «розбірки», гангстерські війни, навіть якщо вони за характером застосовуваних у них методів боротьби не відрізняються від політичних акцій. Відзначається також груповий 
характер терористичної діяльності, але якщо керуватися цим критерієм, то вбивця-одинак, який не входить у терористичну організацію, не може бути визнаний терористом.

Аналіз кримінального законодавства пострадянських держав показує, що криміналізація терористичних проявів здійснюється по-різному i різним чином визначаються ознаки складів злочинів, які передбачають відповідальність за терористичні діяння. Так, ст. 250 («терористичний акт») і ч. 1 ст. 88 («тероризм») КК Латвійської Республіки сформульовані таким чином, що ознаки передбачених тут діянь практично співпадають 3 ознаками складів диверсії, які мають місце, наприклад, у ст. 112 КК України, ст. 360 КК Республіки Білорусь, ст. 281 КК Російської Федерації, ст. 173 КК Республіки Туркменістан, ст. 161 КК Республіки Узбекистан [4].

Слід відзначити, що фактично однакові склади злочинів, які передбачають відповідальність за вчинення вибухів, підпалів та інших загально небезпечних дій, якщо такі дії були вчинені з метою порушення громадської безпеки, залякування населення, провокації воєнного конфлікту, міжнародного ускладнення або з метою впливу на прийняття рішень органами державної влади, міжнародними організаціями, юридичними особами, в ст. 214 КК Азербайджанської Республіки, ст. 289 КК Республіки Білорусь, ст. 217 КК Республіки Вірменія, ст. 226 КК Киргизької Республіки, ч. 2 ст. 88 КК Латвійської Республіки, ст. 179 КК Республіки Таджикистан, ст. 271 Республіки Туркменістан мають назву «тероризм», а в ст. 323 КК Грузії, ст. 205 КК Російської Федерації, ст. 258 КК України мають назву «терористичний акт» [4].

Норми про кримінальну відповідальність за прояви тероризму містяться в законодавстві багатьох європейських держав. Вивчення кримінальних кодексів 25 держав (Австрії, Азербайджанської Республіки, Бельгії, Грузії, Данії, Естонії, Іспанії, Латвійської Республіки, Литовської Республіки, Нідерландів, Норвегії, Республіки Албанія, Республіки Білорусь, Республіки Болгарія, Республіки Вірменія, Республіки Молдова, Республіки Польща, Республіки СанМарино, Республіки Словенія, Російської Федерації, України, Франції, ФРН, Швейцарії та Швеції) показало, що окремі норми про відповідальність за терористичні діяння містяться в більшості з них, а саме у 16 .

Норми, що передбачають кримінальну відповідальність за різні прояви розглядуваних суспільно небезпечних діянь, у своїх назвах, у назвах структурних підрозділів або в текстах диспозицій статей мають різні найменування для їх визначення: тероризм, терористичний акт, терористична дія (КК Норвегії), створення терористичних об'єднань (КК ФРН). Розглядувані норми містяться у структурних підрозділах (розділах чи главах) кодексів, де об'єктом кримінально-правового захисту виступають не поодинокі соціальні цінності, а найчастіше громадська безпека. Громадській безпеці як стану захищеності суспільства притаманна властивість комплексності об'єкта кримінально-правової охорони від неправомірного поводження 3 небезпечними предметами та загально-небезпечними формами поведінки людей, що означає відсутність такої небезпеки для функціонування суспільства, включаючи життя та здоров'я людей, майнові інтереси фізичних і юридичних осіб, нормального функціонування соціальних (державних і громадських) інститутів тощо.

У більшості проаналізованих кодексів стаття про кримінальну відповідальність за тероризм чи терористичний акт складається 3 кількох частин (зокрема, ст. 278 КК Республіки Молдова містить шість частин). У них, як правило, диференціюється відповідальність за тероризм (терористичний акт), хоча в окремих з них можуть формулюватися положення про відповідальність за, по суті, самостійні злочинні діяння. Це мало місце, зокрема, у ст. 258 КК України до внесення відповідних змін до неї [4].

У цьому контексті зазначимо, що в КК Республіки Албанія виділено окрему ст. 233 «Створення озброєних груп» [67], яка міститься в главі VII «Терористичні акти», в КК ФРН є § 129а «Створення терористичних об'єднань», а в КК Грузії ст. 327 « Створення терористичної організації або керування нею, або участь у ній» [4] Таке вирішення розглядуваного питання $є$ доцільнішим. Вважаємо за можливе поставити питання про доцільність вилучення зі ст. 258 КК України положень їі ч. 4, на основі якої створити окрему статтю, в якій би диференційовано передбачалася відповідальність за створення терористичної групи чи організації, керівництво такою групою чи організацією (ч. 1), матеріальне, організаційне чи інше сприяння створенню або діяльності терористичної групи чи терористичної організації (ч. 2), участь у терористичній групі чи терористичній організації (ч. 3).

Підкреслимо, що практично в усіх розглянутих кодексах зарубіжних європейських держав формулювання підстав кримінальної відповідальності за тероризм пов'язане iз зазначенням суб'єктивних ознак злочину. Виняток становить лише КК Латвійської 
Республіки. У ст. 250 «Тероризм» описуються дії без вказівки на певну мету, мотив чи намір [5].

Найчастіше у відповідних нормах йдеться про певну мету вчинення розглядуваного злочину, інколи про певний намір (у ст. 355 «ероризм» КК Республіки Словенія говориться про намір створення загрози для вказаних у законі об'єктів кримінально-правової охорони, зокрема, конституційного устрою; у ст. 234 КК Республіки Албанія про певні способи поводження 3 військовою, хімічною, біологічною, ядерною зброєю 3 наміром вчинити терористичний акт; в абз. 1 § 147а КК Норвегії про караність названих у цьому законів дій як терористичних, якщо вони вчинені з певним наміром, а саме: «а) грубо завадити здійсненню функції, що має основоположне значення для суспільства; b) викликати сильний страх у населення; с) незаконно спонукати офіційну владу або міжнародні організації до здійснення, терпіння стосовно якоїсь дії або бездіяльності, що мають серйозне значення для Норвегії або організації, або іншої країни, або міжнародної організації»); у Пенітенціарному кодексі Естонії про мету і мотив (у ч. 1 ст. 237 ідеться про вчинення певних дій «з метою провокації війни або міжнародного конфлікту або з політичних чи релігійних мотивів»).

Під час конструювання норм про відповідальність за розглядувані злочини системоутворювальну роль відіграють їх суб'єктивні ознаки (мета, намір та мотив), зокрема, у випадках відсилання, зробленого в «антитерористичній» статті кодексу, до інших статей КК чи інших правових актів, що має місце в кодексах Франції, Іспанії, Норвегії.

$\mathrm{y}$ рамках Європейського співтовариства натепер наявна єдина антитерористична політика, що базується на наукових розробках. П'ять європейських держав - Іспанія, Англія, Німеччина, Франція, Італія домовилися між собою розвивати т. зв. «юридичну репресивну стратегію». Ці держави ухвалили законодавство надзвичайного стану а також внесли структурні зміни у чинні законодавчі акти. Одночасно зі створенням або початком роботи зі створення антитерористичного законодавства в Європі почала складатися своєрідна правозахисна система, яка згодом отримала назву «нова юридична культура». 3-поміж цих країн Англія однією 3 перших почала послідовно напрацьовувати антитерористичне законодавство. Парламент країни в 1972 р. прийняв Закон про затримання терористів, який був скасований першим великим антитерористичним законом «Про надзвичайні заходи» від 25 липня
1973 р. 3 доповненнями однойменний закон набув чинності 1978 р.

Антитерористичний закон Англії 1989 р. консолідував попередні закони і вніс низку суттєвих доповнень. Усі зазначені закони передбачають кримінальну відповідальність осіб, які входять до складу будь-яких заборонених організацій; схиляють інших осіб до підтримання таких організацій; влаштовують або допомагають влаштовувати збори заборонених організацій; беруть участь у зборах, що складаються з більше ніж трьох осіб, знаючи, що вони присвячені підтриманню такої організації, розвитку іiї діяльності, виступу членів цієї організації або осіб, що заявляють про приналежність до забороненої організації. У цьому законі є особливий розділ, в якому йдеться про відповідальність за фінансову допомогу терористам. Будьяка особа, яка субсидує фонд терористичної діяльності або схиляє до цього інших осіб, незалежно від того, надається фінансова допомога в обмін на щось або безкорисливо, звинувачується в сприянні тероризму.

До 1986 р. французьке кримінальне право не розглядало тероризм як самостійний вид злочину. Притягнення до кримінальної відповідальності і покарання за найбільш тяжкі злочини, в тому числі і за терористичні, вчинені на французькій території, здійснювалось 3 урахуванням положень Закону № 8182 «Про посилення безпеки та свободи особистості» від 2 лютого 1981 р. і Закону 83466 «Про скасування та зміну деяких положень Закону № 8182 і доповнення деяких положень Кримінального кодексу» від 10 червня 1983 р. Згідно з положеннями цих законів якщо суд у загальнокримінальних злочинах вбачав елементи тероризму, то він міг, крім основного покарання, застосувати стосовно винного додаткові санкції, як наприклад позбавлення політичних, цивільних і сімейних прав.

У цьому законотворчому процесі, на думку професора Паризького університету Марі-Елізабет Картьє, можна умовно виділити три періоди, кожен з яких істотно вплинув на процес боротьби держави 3 терористичними актами. Перший період, який французькі юристи вважають основним у широкомасштабному наступі на тероризм, починається 3 моменту прийняття 9 вересня 1986 р. Закону № 861020 «Про боротьбу з тероризмом і посяганням на державну безпеку». Другий період пов'язується з прийняттям Закону № 87542 від 16 липня 1987 р. «Про ратифікацію Свропейської конвенції про покарання тероризму». Третій період - з прийняттям у липні 1992 р. нового Кримінального кодексу Франції, який 
набрав чинності 1994 р. У ньому вперше було криміналізовано тероризм як окремий склад злочину у ст. 421422 розділу II книги 4 «Про злочини та проступки проти нації, держави і суспільного спокою». Цей кодекс повністю замінив законодавчий акт, що діяв ще 31810 р. (т. зв. Кодекс Наполеона) [5].

Відповідно до ст. 4211 КК Франції актом тероризму (за наявності мети суттєво порушити громадський порядок шляхом залякування або терору) є, зокрема, злочинні діяння, передбачені ст. 5863 закону від 17 червня 1998 р. № 98467, що регулює застосування Конвенції про заборону розроблення, виготовлення, складування та застосування хімічних видів зброї та про їх знищення від 13 січня 1993 р., а також злочинні діяння, визначені у ст. 1 і 4 Закону від 9 червня 1972 р. № 72467, що забороняє розроблення, виготовлення, зберігання, складування, придбання і передачу біологічних та токсичних видів зброї.

Після відновлення в Іспанії демократії відбулася зміна стратегії держави в боротьбі 3 тероризмом, що характеризувалася прогресивною деполітизацією кримінального переслідування злочинців, виключенням інкримінації (презумпції винуватості) у тероризмі завдяки змінам до додатка до Кримінального кодексу Королівським Декретом-Законом від 4 січня 1977 р. Свій розвиток антитерористичне законодавство продовжує з прийняттям 29 грудня 1978 р. нової Конституції Іспанії, ст. 552 якої визнає конституційність певних обмежень прав громадян, коли йдеться про попередження чи розслідування терористичних злочинів. Наступним кроком у законодавчому регулюванні боротьби з тероризмом є Королівський Декрет-Закон № 3/1979 «Про безпеку громадян», що містить норми, спрямовані на боротьбу з тероризмом, які не увійшли до Кримінального кодексу. А сам Кримінальний кодекс був доповнений Органічним законом від 4 травня 1981 р. у частині, що стосується заколоту і тероризму, специфічними кримінальними деліктами: вступ у збройні банди і терористичні організації, конспірація і пропозиція іх створити, підбурювання і вихваляння подібних формувань. Норми про тероризм виносяться за рамки Кримінального кодексу для того, щоб стати об'єктом спеціального закону, який, перегрупувавши їх у сукупність кримінальних і процесуальних положень, буде застосовувати їх у боротьбі з цим злом. Цій же меті був підпорядкований Органічний закон від 26 грудня 1984 р. «Про боротьбу з озброєними бандами i терористичними елементами», прийнятий на виконання ст. 552 Конституції 1978 р. і визнаний більшістю як закон, спрямований на посилення боротьби з тероризмом [5].

Підкреслимо істотне значення у боротьбі 3 тероризмом Органічного закону № 10 «ро Кримінальний кодекс» від 23 листопада 1995 р., яким було введено в дію новий Кримінальний кодекс Іспанії. У цьому Кодексі значне місце відводилося положенням, що стосуються тероризму. Це, зокрема, відділ 2 «Про тероризм» глави 5 «Про володіння, торгівлю та зберігання зброї, боєприпасів або вибухових речовин і тероризм» розділу 22 «Злочини проти громадського порядку» книги 2 «Злочини і покарання». У нормах, що містяться у статтях відділу 2, іспанський законодавець описує умови, за наявності яких вчинені дії визнаються терористичними, а також санкції за них [5].

У 1976-1978 р. у Німеччині сталося кілька терористичних актів. Реакцією держави у відповідь було прийняття антитерористичного законодавства. На думку німецьких юристів, прийняття такого законодавства продиктовано не зростанням терористичної загрози, а прагненням держави захистити суспільство від неконтрольованих дій, інспірованих керівниками лівих студентських рухів.

19 грудня 1986 р. у ФРН бундестат ухвалив Закон про боротьбу з тероризмом, яким включено до Кримінального кодексу три нові норми, втілені у ст. $129 \mathrm{a}$, ст. $130 \mathrm{a}$, ст. $305 \mathrm{a}$ Згідно зі ст. 129а КК («Створення терористичних об'єднань») караються позбавленням волі на строк від 1 р. до 10 років особи, котрі заснували об'єднання чи брали участь як члени в об'єднанні, діяльність якого спрямована на вчинення таких посягань: тяжке вбивство, просте вбивство або геноцид; злочини проти особистої свободи (викрадення людей з метою вимагання, викупу, захоплення заручників), злочини, передбачені в ст. 305а (руйнування важливих засобів виробництва), загально-небезпечного злочину, передбаченого в ст. ст. 306-308, ст. 319 КК Німеччини (тяжкий підпал, особливо тяжкий підпал; дії, що спричинили ядерний вибух або звичайний вибух; зловживання іонізуючим випромінюванням; дії, що спричинили затоплення або повінь, що загрожують життю людей; порушення роботи дорожнього, водного або повітряного транспорту, що спричинили небезпеку для життя, здоров'я або майна людей; порушення роботи підприємств залізниці, пошти, телеграфу та інших установ, що забезпечують життєво важливі потреби населення, отруєння водойм загального користування). Ініціатори таких об'єднань караються позбавленням волі на строк не менше 3 років. 
Згідно зі ст. 130а КК, за заклики до вчинення злочинних діянь особі загрожує покарання у вигляді позбавлення волі на строк до трьох років або великий штраф. А згідно зі ст. 305а КК, за руйнування важливих засобів виробництва відповідає той, хто протиправно руйнує повністю або частково чужий технічний засіб виробництва значної цінності.

У період з 1974 р. до поч. 80-х р. в Італії прийнято низку законодавчих актів антитерористичного змісту. Так, у грудні 1979 р. набув чинності Закон про термінові заходи щодо захисту демократичного порядку та громадської безпеки. У 1980 р. у КК Італії імплементовано статтю $270 б$ в якій передбачена відповідальність осіб, котрі організовують групи людей з кінцевою метою вчинення тероризму і руйнування демократичного ладу. За скоєння такого діяння призначається покарання у вигляді тюремного ув'язнення на термін від 7 до 15 років, а за співучасть у подібному посяганні - від 4 до 8 років.

\section{Висновки}

Отже, можемо констатувати: 1) антитерористичному законодавству країн Західної Свропи характерні спільні єдині тенденції ставлення до такого негативного кримінального явища, яким загальновизнано тероризм; 2) у кримінально-правовому регулюванні питань відповідальності за тероризм у зарубіжних державах проглядається вплив історичних традицій відповідної держави; 3) за результатами аналізу законодавства зарубіжних держав нами не виявлено положень, які доцільно негайно й безальтернативно імплементувати у чинне національне законодавство. Забігаючи наперед, слід визнати, що сучасне національне кримінальне законодавство в частині відповідальності за тероризм в основному відповідає європейським тенденціям. Інше питання: чи повністю воно адекватне вимогам сьогодення? Відповідь на це питання потребує грунтовного і всебічного аналітичного підходу до напрацювання принципів протидії тероризму з урахуванням детермінації цього виду злочинності.

\section{Список використаних джерел:}

1. Декларація ООН «Про заходи ліквідації міжнародного тероризму» від 09.12.1994. URL: http://zakon.nau.ua.

2. Резолюція 1456 (2003), прийнята Радою Безпеки на іï 4688-му засіданні. URL: http: // zakon2.rada. gov.ua.

3. Тероризм: теоретико-прикладні аспекти : навчальний посібник / кол. авторів ; за заг. ред. проф. В.К. Грищука. Львів : ЛьвДУВС, $2011.328 \mathrm{c}$.

4. Терроризм в современном мире. Опыт междисциплинарного анализа (материалы «круглого стола»). Вопросы философии. 2005. № 6. С. 68.

5. Тероризм: теоретико-прикладні аспекти : навчальний посібник / кол. авторів ; за заг. ред. проф. В.К. Грищука. Львів : ЛьвДУВС, 2011. 328 с.

The article provides an overview of the anti-terrorism legislation of the countries of Western Europe. The common tendencies towards such a negative criminal phenomenon, which are generally recognized, are revealed. Terrorism is considered from the point of view of criminal regulation of issues of responsibility for terrorism in foreign countries, which examines the influence of the historical traditions of the respective state. According to the results of the analysis of the legislation of foreign states, we have not identified any provisions which are expedient to immediately and without alternative be implemented in the current national legislation. It is determined that the pace of elaboration of own definitions of the term "terrorism" and their consolidation in national legislation depend largely on how long certain states have faced this problem and how far the confrontation between their own power structures and society, on the one hand, and terrorists has gone, organizations from another. It is emphasized that in most countries the article on criminal responsibility for terrorism or terrorist act consists of several parts. As a rule, they differentiate responsibility for terrorism (terrorist act), although in some of them the provisions on responsibility for, in essence, independent criminal acts can be formulated. The following conclusions are drawn: 1) the anti-terrorist legislation of the countries of Western Europe is characterized by common tendencies towards such a negative criminal phenomenon, which is widely recognized; 2) terrorism in the criminal law regulation of issues of responsibility for terrorism in foreign countries examines the influence of the historical traditions of the respective state; 3 ) according to the results of the analysis of the legislation of foreign states, we have not identified any provisions that are expedient to immediately and alternatively implement into the existing national legislation. Looking ahead, it should be acknowledged that current national criminal law, in terms of responsibility for terrorism, is broadly in line with European trends. Another question: is it fully adequate to the requirements of today? The answer to this question requires a thorough and comprehensive analytical approach to working out the principles of counter-terrorism, taking into account the determination of this type of crime.

Key words: anti-terrorist legislation, terrorist group, terrorist organization, imprisonment. 